\title{
Estonia and Lithuania in transition: A compared analysis of the change and its costs and benefits
}

\author{
Giulia Pilia \\ MA Graduate, University of Bologna, Italy
}

\begin{abstract}
On the aftermath of the dissolution of the Soviet Union, the newly independent republics had to face a choice over which economic system should be adopted, and how to implement the transition from a planned economy to market economy system.

The aim of this paper is to provide a brief overview of the transition process in the cases of Estonia and Lithuania, two countries with a similar history but with significant differences on the social, economic and cultural background. The two countries undertook two different sets of transition reforms: while the first country chose the path of the so called "shock therapy", Lithuania opted for a more gradual transition. The paper will bring a comparative analysis of the two transitions and of its different outcomes after approximately 25 years of transition.
\end{abstract}

Keywords: transition, post-soviet, Lithuania, Estonia, shock therapy.

\section{JEL Classification: N.}

DOI: $10.21272 /$ bel.1(2).12-19.2017.

(C) The Authors, 2017. This article is published with open access at ARMG Publishing.

\section{Introduction}

The three Baltic Republics of Estonia, Latvia and Lithuania, although being often considered to be relatively similar countries, actually strongly differ from a cultural, social and economic point of view. These differences became evident when these countries, together with the other former Soviet Republics, had to face the shift towards independence, facing the choice of a practicable path.

The aim of this paper is to provide a brief overview of the transition process by taking the case study of Estonia and Lithuania, two countries that, despite the common geographic and historical features, portray different outcomes. This will be displayed through compared analysis of the different post-communist transitions and its costs.

Thus, at first the two reform systems - gradual transition and rapid transition - will be illustrated, together with the countries' background diversities. Then it will be explained how the reforms were implemented; a comparison based on the data analysis will follow, showing the costs and benefits of the transition.

\section{Rush for transition}

The new decade of the Nineties marked the end of an era throughout the whole Soviet bloc.

With the failure of the Communism, a whole economical and cultural system fell apart, and the former communist countries had to face the choice of their own system: the inclination was towards a Western social model, seen as flourishing and democratic, in order to detach from the previous Soviet model.

The transition had to shift from a planned economy system to market economy system, and this implied radical reforms aimed at turning the society upside down.

Thus, the crucial question appeared to be the following: how to implement a post-communist transition? Should the changes be carried out radically or with a more careful approach?

The debate on the speed divided the intellectuals' opinion in two specific reform strategies: radical reformers, supporting the so-called "shock therapy", and gradual reformers, promoting a smoother transition.

The main supporters of the radical programme of reforms were the IMF, the World Bank and the U.S. government, who believed that a radical and comprehensive reform program would be the best cure to the break with the Communist system. The set of specific economic policy reforms was called "Washington 
Consensus"1 (Myant, 2010), and embraced policies in the areas of macroeconomic stabilization, economic opening (concerning both trade and investment) and the expansion of market forces within the domestic economy, aiming to the immediate stabilisation and liberalisation of the post-communist economies, whereas the development of social policies should be "second ordered" policy objectives.

On the other hand, the gradual reformers, who were mostly Keynesians, or had sympathy towards Socialism, pressed more on first carrying out institutional changes, such as privatisation, and then building stabilisation and market liberation (Åslund, 2007).

Estonia and Lithuania are here chosen as two cases to illustrate the two different reform strategies for transition. The two countries here examined followed different paths: on the whole, the transition in Estonia followed the radical approach, whereas Lithuanian transition has been more gradual.

For a deep understanding of the different outcomes which followed these two transitions, it is crucial to give an overview of the background diversities of Estonia and Lithuania.

\section{Background diversities}

Although the two countries had a common past, there are significant differences in their development paths and in their internal structures, both in the socio-political and economic spheres.

While in the early Nineties the Estonian production system was rather industrialized and developed early ${ }^{2}$, the Lithuanian industrial system, which was built during Soviet times, was relatively recent. The society was more agricultural-oriented, as it remained tied to the Soviet system (Mygind, 1998).

This aspect had particular influence on the local ethnic component: among the three Baltic Republics, Lithuania was the one which presented the lowest presence of Russian immigrants. In Lithuania there was enough llabor force, coming from the agricultural sector, to supply the developing industrial sector; thus, the need for additional llabor force, which meant Russian immigrants, had been lower'

The situation was different in Estonia, where in the larger cities the Russian speaking population made up almost the half (43\%) of the industrial llabor force (Mygind, 1998).

Another relevant aspect is the one that Mygind defines as "value system", that is the set of differences in tradition, religion and language, which creates a line of separation and also interacts with the surrounding world.

For what concerns religion, Estonia is a Protestant country, while Lithuania is deeply Catholic. This difference is related to Lithuania's close historical links with Poland, whereas Estonia was strongly influenced by German culture, also due to the presence of the Baltic Germans. This also contributes in explaining the early industrialization of Estonia.

Moreover, for linguistic reason, Estonia benefitted from close contacts with Finland, which was an open window towards Western Europe; in addition, in the northern part of Estonia the population could even receive Finnish radio and television, facilitating the relations with Finland. Lithuanian language, on the other hand, belongs to the Baltic branch, like Latvian, but the two languages are not so close to allow direct communication: this language barrier implied that the influence of Western lifestyle was less noticeable.

It can be useful to display these differences in a table:

\begin{tabular}{|l|l|l|}
\hline \multicolumn{1}{|c|}{ Country } & \multicolumn{1}{|c|}{ Estonia } & \multicolumn{1}{c|}{ Lithuania } \\
\hline Production system & Early industrialisation & $\begin{array}{l}\text { Society more agricultural-oriented; } \\
\text { industrialisation in Soviet times }\end{array}$ \\
\hline Ethnic component: Russian presence & $30.3 \%$ of population ethnic Russians & $9.4 \%$ of population ethnic Russians \\
\hline Value system & $\begin{array}{l}\text { Religion: Protestant } \\
\text { Language: Finno-Ugric }\end{array}$ & $\begin{array}{l}\text { Religion: Catholic } \\
\text { Language: Baltic }\end{array}$ \\
\hline Previous contacts with: & Germany, Finland & Poland \\
\hline
\end{tabular}

\footnotetext{
${ }^{1}$ The name was created by the economist John Williamson, and it was initially meant to indicate a set of ten economic measures for countries in transition or facing a crisis.

${ }^{2}$ In the 1930s Estonia had alredy developed a light industry sector.

${ }^{3}$ According to the 1989 Soviet census, Russians made up $30.3 \%$ of the population in Estonia, while only $9.4 \%$ of Lithuania's population were ethnic Russians (Sakwa, 1998).
} 


\section{Why gradual? Why rapid?}

As already mentioned, Estonian transition was implemented radically, while Lithuanian transition has been more gradual.

The choice over the transition approaches was not done totally freely: there were several limitations which prevented Lithuania from carrying out a similar shock therapy.

The first one was the political situation of the country: the political and social setting did not allow the government to act easily. At the 1992 parliamentary elections the Llabor party, which had roots going back to the former Lithuanian Communist party, won the majority in parliament, and on the 1993 elections its leader Algyrdas Brazauskas was elected as president (O’Connor, 2003). Nevertheless, the Llabor party could benefit of a poor majority: the party won 73 sits, when the minimum for obtaining the majority was 71 out of 141 (Sikk, 2001); the government was also divided by internal conflicts, especially on issues concerning the finance ministries ${ }^{4}$. Moreover, the working class, as previously said, mostly composed by ethnic Lithuanians, had a relatively strong political position, and being the first victims of the free market and radical foreign trade regime, they often opposed to the opening market reforms.

On the contrary, in Estonia the reform process was easier: the political vacuum on the left allowed the government to implement the reforms without a strong political opposition.

After winning the 1992 parliamentary elections, Mart Laar's conservative party "Fatherland" started to carry out the so called "shock therapy", following the Washington Consensus regulations.

\section{How the transition worked}

The transition in Estonia started already during the late Eighties with the establishment of many semiprivate enterprises and joint ventures with foreign companies, but this process was not completed by the end of the decade. In May 1989, the Estonian RSS government designed a reform programme which planned to establish an independent Estonian economy with its own currency, a Central Bank and an ownership structure consisting of both state-owned enterprises, private joint-stock, and employee-owned companies (Mygind, 1998).

Nevertheless, the most significant reforms were undertaken in the early Nineties: a crucial point was the introduction of a new tax system and the tightening of the monetary policy, set by the Bank of Estonia, which drastically increased the interest rates.

An important prerequisite of privatisation was reforming the currency: in June 1992, Estonia's own currency, the kroon, was introduced. As suggested by the Washington Consensus, as it was done in Poland in 1990 and in Czechoslovakia in 1991, the local currency was soon tied to the Estonian reserves of hard currency and gold and, most importantly, pegged first to the Deutsche Mark (the pegged rate was 8 to 1) and later to the euro during the entire circulation period (Knöbl et al., 2002). This strategy was fundamental for the economic stabilisation of the financial system.

Another important step listed by the Washington Consensus was the privatisation process: Estonian government decided to give preference to the sale to outside owners rather than using the vouchers system, and Estonia was the first country to use privatisation for the promotion of foreign investment. Already from 1993 on, foreigners took over some of the largest enterprises under privatisation process, and by the end of 1998, foreign investors had taken over approximately one third of enterprise assets, whereas in Lithuania only 4 enterprises out of 46 were taken over by foreign investors by 1995 (Mygind, 1999).

There is also another aspect that is worth to be pointed out: the positive attitude toward cooperative and individual activity. This aspect was studied and quantified by Hans Aage, who analysed the percents of respondents having the before mentioned positive attitude. According to his studies, in the whole Soviet Union this percentage was equal to $15 \%$ in 1990. In the three Baltic Republics the rate accounted for $30 \%$ in Estonia, 22\% in Latvia and 15\% in Lithuania (Aage, 1991). The data show that the Estonian population was more familiar with the open economy than the Lithuanian one. It also shows a higher degree of individual

\footnotetext{
${ }^{4}$ By implementing the needed reforms, the Llabor government lost its popularity, loosing the 1996 elections against the Homeland Union, a Western-oriented conservative party.
} 
values in Estonia, while in Lithuania it illustrates a more collective and equalitarian set of values, closer to the figure of the rest of Soviet Union.

This attitude is also reflected in the outlook towards foreign direct investments (FDI): Lithuania was more unwilling to open up for foreign capital, especially for what concerned the enterprises considered to be of strategic importance. Mygind finds a reason in the fact that the opposition parties particularly feared Russian investors and were against the implementation of liberal rules which would allow foreigner investors to buy land (Mygind, 1995).

The attitude in Estonia was different: the government put into actions several liberal rules, aiming to open up to the inflow of foreign capital, especially from Finnish and Swedish investors.

Thus, it is clear how and why Estonia actually showed an urge towards the open market economy, whereas Lithuania followed a gradual strategy placing more concern on the survival of institutional resources.

In Lithuania, indeed, the stabilization was weaker in the first years of transition. Compared to Estonia, the country stayed longer in the ruble zone: the new currency, litas, was introduced in June 1993, and in April 1994 the currency was pegged to the dollar (Mygind, 1999) with a pegged rate of 4 to 1.

During the initial stage of reforming its economy, Lithuania faced numerous problems with the transformation from state-owned property to private property. A feature of the local economy was that a large number of the most important enterprises were directly subordinated to institutions of the Soviet Union, and the process of changing this structure took a long time, also due to the already mentioned political issues, and required serious efforts.

To a high degree, the privatisation was based on social arrangements and on the distribution of free vouchers to every adult person with the intent of spreading the ownership among the population: while in Estonia the majority of vouchers were related to the privatisation of land and housing, in Lithuania $65 \%$ of the vouchers were used in enterprise privatisation. This percentage in Estonia amounted only to the 26\% (Mygind, 1999).

It is useful to sum up the previous concepts in a second table:

\begin{tabular}{|l|l|l|}
\hline \multicolumn{1}{|c|}{ Country } & \multicolumn{1}{|c|}{ Estonia } & \multicolumn{1}{c|}{ Lithuania } \\
\hline Currency & $\begin{array}{l}\text { Kroon, established in June 1992. } \\
\text { Pegged first to Deutsche Mark and } \\
\text { later to Euro. }\end{array}$ & $\begin{array}{l}\text { Litas, established in June 1993. } \\
\text { Pegged to Dollar. }\end{array}$ \\
\hline Privatisation & $\begin{array}{l}\text { Mainly sold to outside owners; partial- } \\
\text { ly vouchers system; reprivatization of } \\
\text { housing and land. }\end{array}$ & $\begin{array}{l}\text { Mainly voucher system: vouchers for all } \\
\text { citizens; advantages to insiders; reprivati- } \\
\text { zation of housing and land. }\end{array}$ \\
\hline $\begin{array}{l}\text { Positive attitude toward cooperative and } \\
\text { individual activity }\end{array}$ & $30 \%$ & $15 \%$ \\
\hline FDI & Facilitated & Not facilitated \\
\hline
\end{tabular}

\section{Costs and benefits}

The two therapies, even if at a different degree, soon appeared to be effective. Nevertheless, the effects of a sudden opening-up were very harsh on the short run: high inflation rate (according to the IMF sources, in Estonia in 1994 the inflation rate was $47.7 \%$ ) and a sharp increase of the unemployment rates (see appendix A) due to the shock caused by the sudden openness: having now to compete with the world economy, the post-communist economies had to close the technological and industrial gaps to bridge the differences with the rest of the world. Many jobs were destroyed and others were created, and in the in-between process, the so called "job reallocation", the first consequence was an increased unemployment.

However, the data show also the immediate effects of the market economy: soon after the opening-up, the two countries, particularly Lithuania, also due to the geographical position of the country, its larger dimension and population, started developing an increasing exchange of goods with the rest of the world (see appendix B).

\section{Which model was more successful?}

Estonian economy managed to recover from the shock therapy quite successfully: while in the short run the transition brought to harsh and difficult outcomes for the Estonian economy, in the long run it cannot be 
denied that this transition proved to be a sort of "economic miracle", as the 1992 Estonian prime minister Mart Laar himself defined it. The country managed to overcome the initial slump, even managing to satisfy the Maastricht criteria and enter into the Eurozone in 2011, a process that Lithuania completed in 2015.

The present situation in Lithuania, from a merely economic point of view, is not as successful as in Estonia. An index of this, even if often criticized for being misleading, is the GDP pro capita: according to the 2015 World Bank data, Lithuanian GDP pro capita is \$14.252, while the Estonian one is higher (\$17.085).

From this point of view the shock therapy in Estonia can be said to be more successful than the gradual transition in Lithuania. However, if looking at the percentage of population below poverty line, in spite of Estonia's high economic achievements, in 2013 its percentage was $21.8 \%$, whereas the figure in Lithuania equals to $19.1 \%$ (World Bank data). Also, Lithuanian GDP seems to be growing faster than the Estonian one (1.8\% vs. $1.4 \%, 2015$ Word Bank data).

Thus, the answer to the question about which model was more successful cannot be univocal: overall, from an economic point of view it can be said that the shock therapy has been rather successful. But this went to the detriment of the social aspect which, as shown by the previous data, sharply suffered from the effect of a transition which went too fast.

\section{References}

1. Aage, H. (1991). Popular Attitudes and Perestroika. Soviet Studies.

2. Åslund, A. (2007). How Capitalism was Built: The Transformation of Central and Eastern Europe, Russia, and Central Asia, Cambridge University Press.

3. Knöbl, A., Sutt, A, and Zavoico, B. (2002). The Estonian Currency Board: Its Introduction and Role in the Early Success of Estonia's Transition to a Market Economy. IMF Working Paper No. 02/96. Washington, D.C.: International Monetary Fund.

4. Maldeikis, E. (1996). Privatisation In Lithuania: Expectations, Process and Consequences, Heriot-Watt University, Riccarton, Edinburgh: Centre for Economic Reform and Transformation.

5. Myant, M. and Drahokoupil, J. (2010). Transition Economies: Political Economy in Russia, Eastern Europe, and Central Asia, Wiley-Blackwell.

6. Mygind, N. (1998). The internationalization of the Baltic economies, University of Berkeley, California, BRIE Working Paper n. 130.

7. Mygind, N. (1999). Privatisation, governance and restructuring of enterprises in the Baltics. Copenhagen: Centre for East European Studies, Copenhagen Business School.

8. Mygind, N. (1994). Societies in Transition, Copenhagen: Centre for East European Studies, Copenhagen Business School.

9. O' Connor, K. (2003). The History of the Baltic States. Westport: Greenwood Publishing Group.

10. Sakwa, R. (1998). Soviet Politics in Perspective. London: Routledge.

11. Sikk, A. (2011). Elections in the Baltic States, 1992-2011, University College of London online resources.

\section{Additional data resources:}

1. IMF CD - International Monetary Fund Website.

2. OECD - Organisation for Economic Co-operation and Development.

3. World Bank. 
Appendix A. Unemployment rate in Estonia and Lithuania from 1991 to 2016

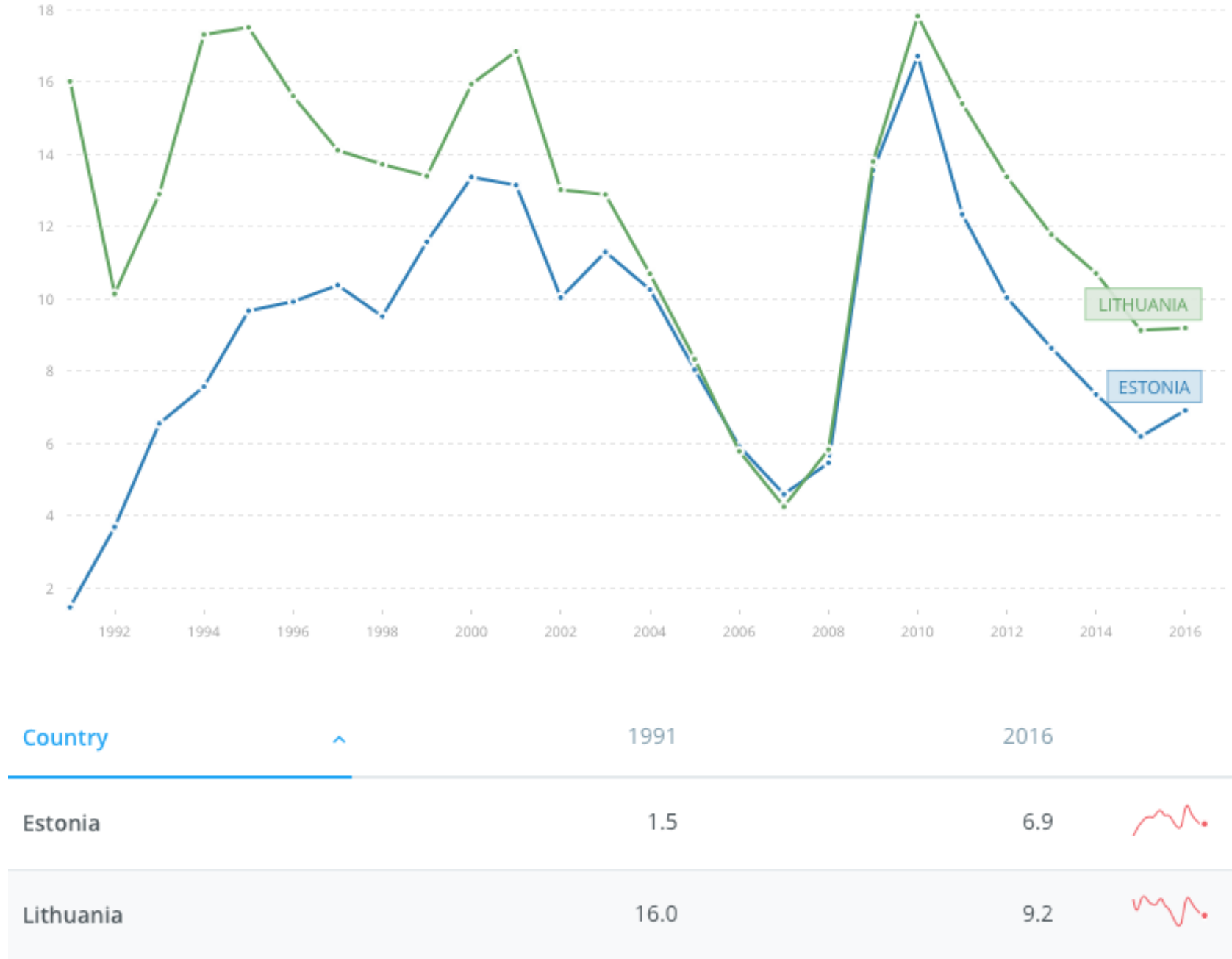

Source: World Bank. 
Appendix B. Imports and export of goods in Estonia and Lithuania (2012)

IMF Data Mapper ${ }^{\circledR}$ Imports of Goods (Annual) (Billions of US Dollars)

- Estonia

- Lithuania

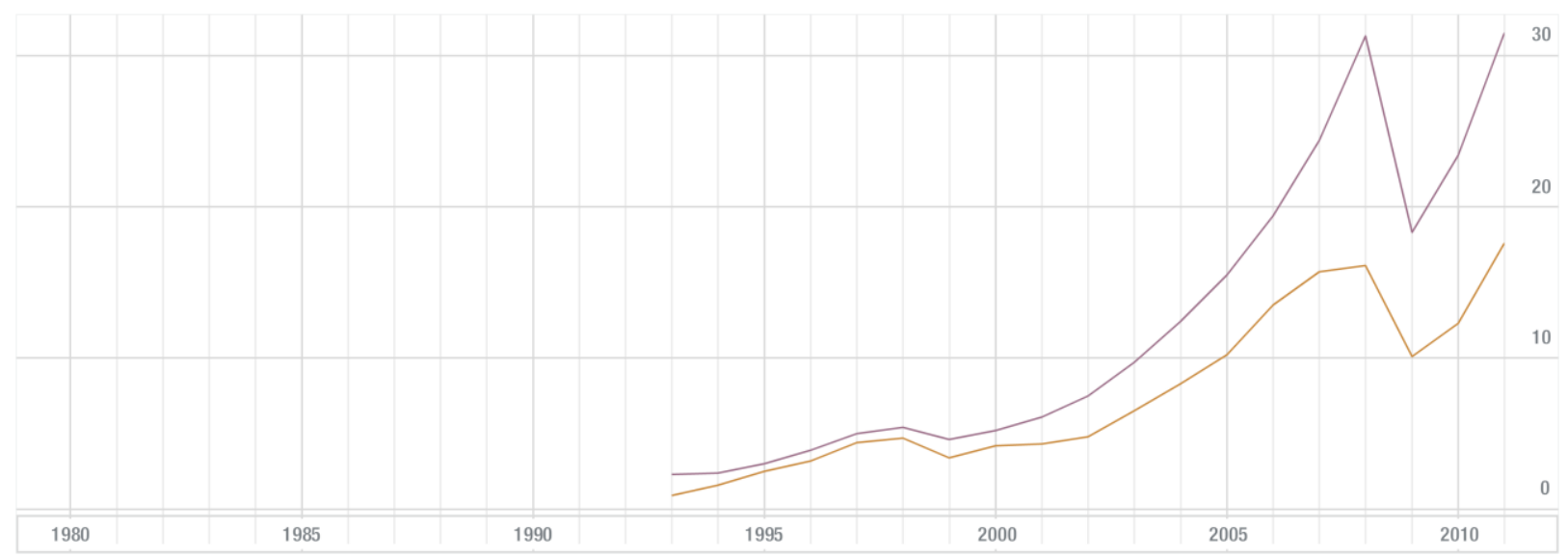

OIMF, 2012, Source: International Financial Statistics (IFS) 2012

IMF Data Mapper ${ }^{\circledR}$

Exports of Goods (Annual) (Billions of US Dollars)

- Estonia

- Lithuania

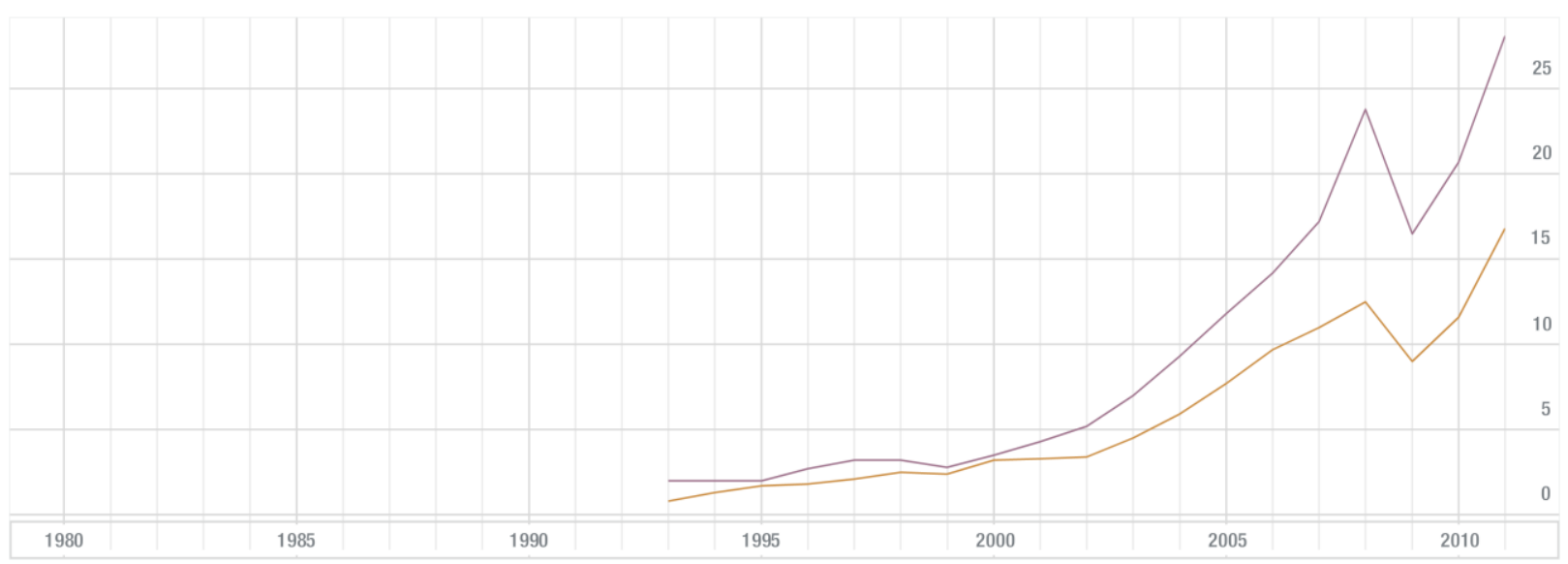

OIMF, 2012, Source: International Financial Statistics (IFS) 2012

Source: World Bank. 


\section{Appendix C. GDP growth in Estonia and Lithuania (2015)}

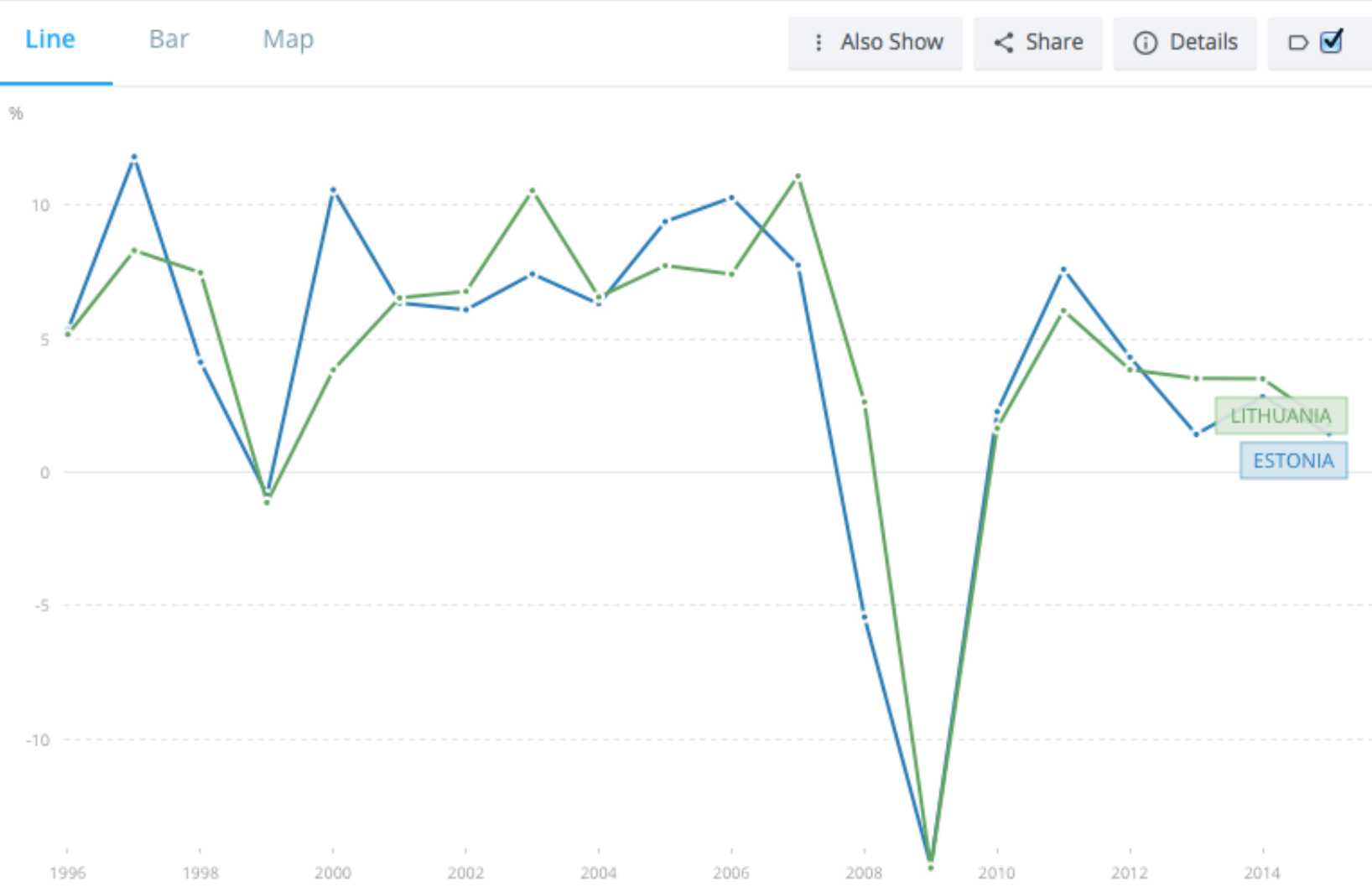

$1996-2015$

Source: World Bank. 